

How Judges Think 



\section{How Judges Think}

\section{Richard A. Posner}

HARVARD UNIVERSITY PRESS

Cambridge, Massachusetts

London, England 
Copyright @ 2008 by the President and Fellows of Harvard College All rights reserved

Printed in the United States of America

First Harvard University Press paperback edition, 2010

A Caravan book. For more information, visit www.caravanbooks.org

Library of Congress Cataloging-in-Publication Data

Posner, Richard A.

How judges think / Richard A. Posner.

p. $\mathrm{cm}$.

Includes index.

ISBN 978-0-674-02820-3 (cloth : alk. paper)

ISBN 978-0-674-04806-5 (pbk.)

1. Judicial process. 2. Judicial process-United States. I. Title.

K2300.P67 2008

$347^{\prime} .012-\mathrm{dc} 22 \quad 2007037826$ 